\title{
NEW RECORDS OF PENESTOGLOSSA DARDOINELLA (MILLIÈRE, 1863) AND EOCHORICA BALCANICA (REBEL, 1919) (LEPIDOPTERA: PSYCHIDAE) ON THE BALKAN PENINSULA
}

\author{
Ana Nahirnić ${ }^{1}$ \& Stoyan Beshkov ${ }^{2}$ \\ National Museum of Natural History, Tsar Osvoboditel Blvd.1, 1000 Sofia, Bulgaria; \\ (e-mails: ${ }^{1}$ ananahirnic@nmnhs.com, ${ }^{2}$ stoyan.beshkov@gmail.com)
}

Nahirnić, A. \& Beshkov, S.: New records of Penestoglossa dardoinella (Millière, 1863) and Eochorica balcanica (Rebel, 1919) (Lepidoptera: Psychidae) on the Balkan Peninsula. Nat. Croat., Vol. 25, No. 2., 305-313, Zagreb, 2016.

Penestoglossa dardoinella (Millière, 1863) was found for the first time in Bulgaria. Finding of this species in southeastern Bulgaria extends its known distribution further to the east. Additional records are given for Greece and one is confirmed for Croatia. New and confirmed records of Eochorica balcanica (Rebel, 1919) are provided for Bulgaria, Former Yugoslav Republic of Macedonia and Greece. This species has also been collected in southern Serbia which makes it a new member of the Serbian fauna. Previously published data on these two species and new data are presented on the map.

Key words: Eochorica balcanica, Penestoglossa dardoinella, Psychidae, distribution, Balkan Peninsula

Nahirnić, A. \& Beshkov, S.: Novi nalazi vrsta Penestoglossa dardoinella (Millière, 1863) i Eochorica balcanica (Rebel, 1919) (Lepidoptera: Psychidae) na Balkanskom poluotoku. Nat. Croat., Vol. 25, No. 2., 305-313, Zagreb, 2016.

Penestoglossa dardoinella (Millière, 1863) nađena je prvi puta u Bugarskoj. Nalaz ove vrste u jugoistočnoj Bugarskoj proširuje njeno poznato rasprostranjenje dalje na istok. Daju se dodatni nalazi za Grčku i jedan potvrđen za Hrvatsku. Novi i potvrđeni nalazi Eochorica balcanica (Rebel, 1919) se daju za Bugarsku, bivšu jugoslavensku Republiku Makedoniju i Grčku. Ova vrsta je prikupljena i u južnoj Srbiji što je čini novim članom faune Srbije. Prethodno publicirani podaci o ovim vrstama i novi podaci prikazani su na karti.

Ključne riječi: Eochorica balcanica, Penestoglossa dardoinella, Psychidae, rasprostranjenost, Balkanski poluotok

The Psychidae family is one of the less studied Lepidoptera on the Balkan Peninsula. By domestic authors, the family has mostly been mentioned occasionally and usually in faunistic publications which included more Lepidoptera families. Here we provide a review of the distribution of two Psychidae on the Balkan Peninsula - Penestoglossa dardoinella (Millière, 1863) and Eochorica balcanica (Rebel, 1919). Our paper contains results of lepidopterological field surveys on the Balkan Peninsula by several collectors carried out in last 25 years. We also include some additional unpublished data from museum collections: Institute of Biodiversity and Ecosystem Research - Bulgarian Academy of Sciences - IBER-BAS, Museum Witt München - MWM, Zoologische Staatssammlung München - ZSM and Tirolean Landesmuseen, Ferdinandeum, Innsbruck, Austria - TLMF. Collecting of cases and rearing, not only light trapping, would increase number of records of these two species. 


\section{Penestoglossa dardoinella (Millière, 1863)}

Male and female have elongated wings with strongly curved tips. In males the forewing is of light grey to dark brown colour and has variable darker spots; the hindwing is of one colour from light grey to dark brown. Females are larger with a lighter wing colour and less prominent spots on the forewing. Male has bipectinate while the female has filiform antennae. Flight period is from late June to the beginning of September (Rebel, 1940). It occurs in France, Greece, Italy, Malta, Spain (SAuter \& Hättenschwiler, 1996), Croatia (Rebel, 1940) and Turkey (Sовсzyк et al., 2016). Reports from Algeria (Chrétien, 1916) probably refer to Penestoglossa gaetula Sobczyk, Bläsius \& Nuss, 2016 while those from Morocco and Tunisia (REBEL, 1940) should be considered to belong to other Penestoglossa species (Ковсzук et al., 2016).

P. dardoinella is a very rare and local species on the Balkan Peninsula. The report of Rebel (1916) after material collected by Tschorbadjiev in 1911 near Sliven Town in Bulgaria in fact concerns another species, not described by that time - Eochorica balcanica. SAUTER \& HätTENSCHWILER (1996) were the first to mention it for Greece. Their source remains unknown to our knowledge. This was the only existing information for Greece until recently, when Sовсzук (2013) reported it from Parnassus and Agios Stefanos and Sовсzук et al. (2016) for island of Chios. The earliest reliable record of $P$. dardoinella in Greece is that from Strymon Delta from 1983. One male specimen was collected in the same day and locality as E. balcanica and placed together with several specimens of $E$. balcanica in the collection of the MWM. From this material, W ттт (1985) mentioned only E. balcanica. Our report from Split from 1928 only confirms a historical record from RebEL (1891). It is alarming that last published data on P. dardoinella in Croatia originate from

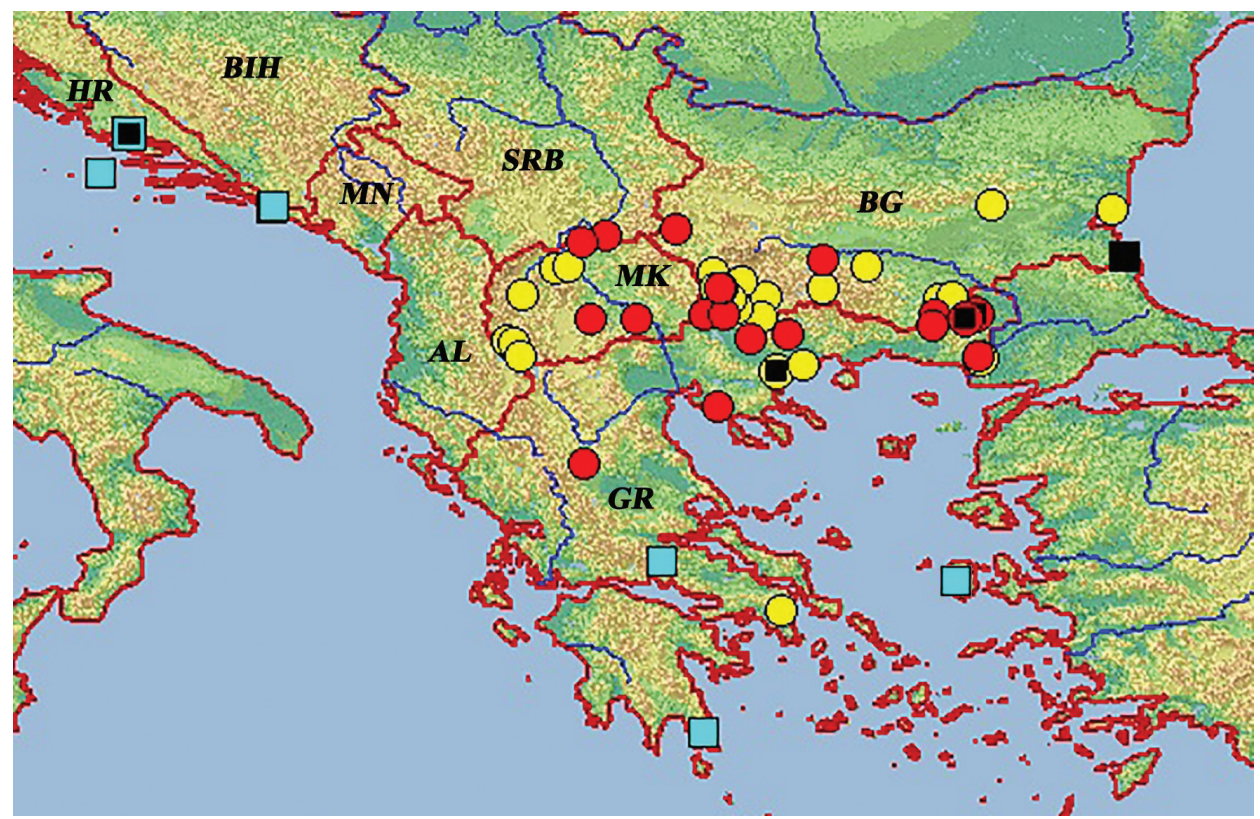

Fig. 1. Distribution of Penestoglossa dardoinella (Millière, 1863) (blue squares - published records, black squares - new records), and Eochorica balcanica (Rebel, 1919) (yellow circles published records, red circles - new records) on the Balkan Peninsula. 
Rebel (1940), yet with no year of collecting, which was at least 76 years ago. The gap between Croatia and Greece exists probably due to poor research on Lepidoptera especially Microlepidoptera in Albania and Montenegro. P. dardoinella has previously not been known from Bulgaria. Localities on Eastern Rhodope Mountains are the most inland record on the Balkan Peninsula with almost $70 \mathrm{~km}$ distance from the Aegean Sea. Mt. Stran$\mathrm{dza}$ represents the easternmost point of this species distribution on the Balkan Peninsula and Europe. Two males from Mt. Strandzha are at first glance bigger and darker and show slight difference in valvae. Research on this mountain will be continued.

The following literature was used to compile a map (Fig. 1): GAlvagni, 1909; Rebel, 1891; Rebel in Prinz, 1919; Rebel, 1940; Sовсzyк, 2013; Sobczyк et al., 2016.

\section{Croatia}

Split, 5.viii.1928, $1 \curvearrowright$, Novak (TLMF)

\section{Bulgaria}

Eastern Rhodopes Mts, Ivaylovgrad district, Byala Reka, Zhultichalskoto dere near Meden Buk village, $121 \mathrm{~m}, \mathrm{~N} 41^{\circ} 22^{\prime} 48^{\prime \prime}$, E02601'40”, 25.vii.2012, 10, Quercus, Tamarix, Alnus, leg. S. Beshkov, lamps and light traps

Eastern Rhodopes Mts, Ivaylovgrad district, Likana (Kodzhakaya) between Odrintzi

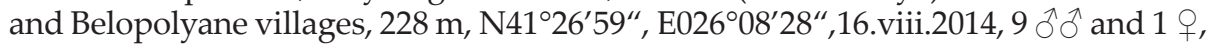
Phyllirea, Juniperus, Acer monspessulanum, Quercus, meadow, leg. S. Beshkov \& S. Abadjiev, lamps and light traps

Eastern Rhodopes Mts, Ivaylovgrad district, Likana (Kodzhakaya) between Odrintzi

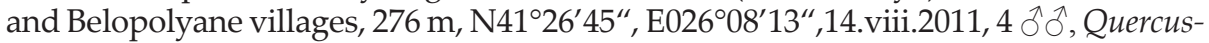
Carpinus forest with Acer monspessulanum and meadows with Juniperus, leg. S. Beshkov, lamps and light traps

S Black Sea Coast-Mt. Strandzha, Papiya Hill above Brodilovo village, 370 m, N42 $06^{\prime} 17^{\prime \prime}$,

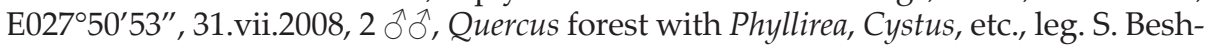
kov, lamps and light traps (Figs 2, 3)

\section{Greece}

Strymon-Delta, 1 km S Nea Kerdilia, 2 m, N4048’, E2351', 26.viii.1983, 1 §ૈ, leg. H. Hacker, LF (MWM)

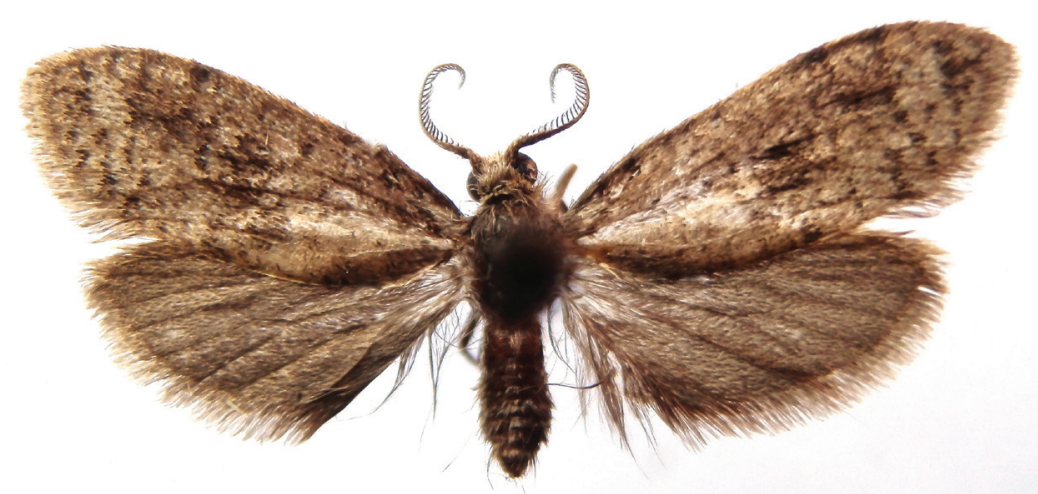

Fig. 2. Male of Penestoglossa dardoinella (Millière, 1863) from S Black Sea Coast-Mt. Strandzha, Papiya Hill above Brodilovo village, $370 \mathrm{~m}$. 


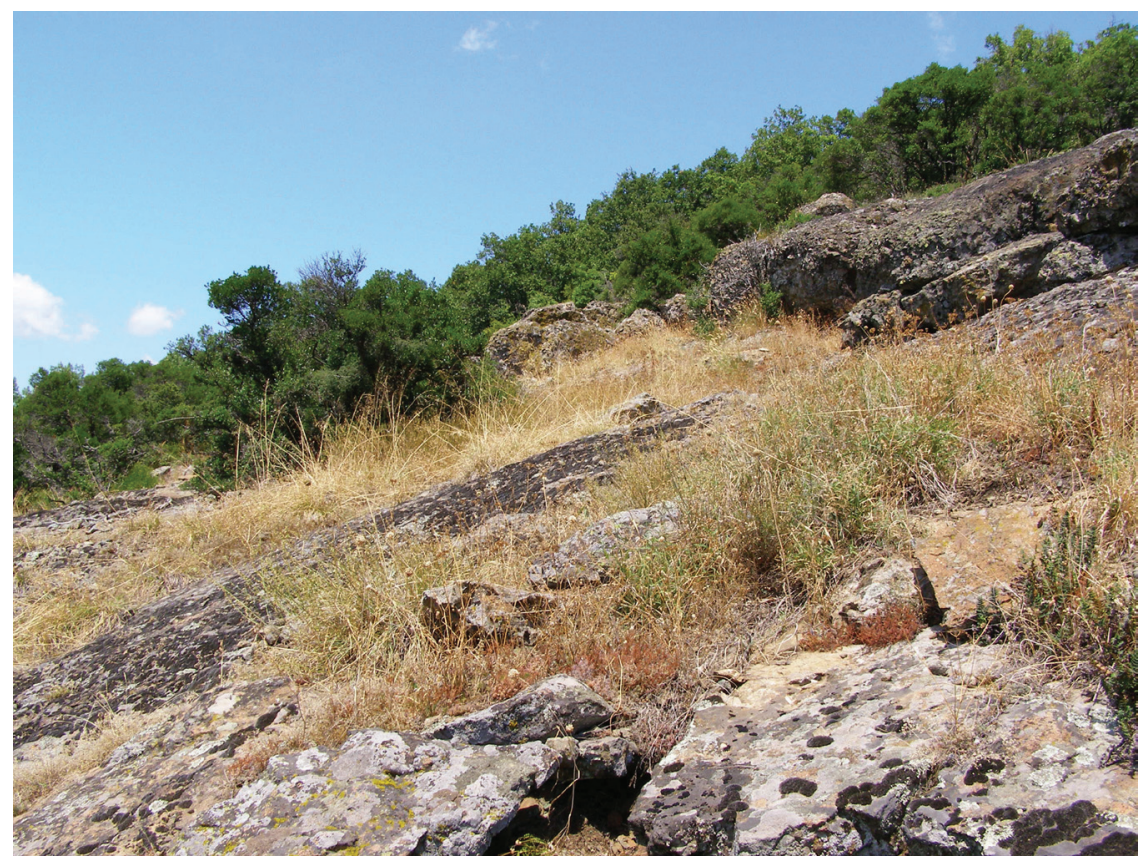

Fig. 3. Habitat of Penestoglossa dardoinella (Millière, 1863) at S Black Sea Coast-Mt. Strandzha, Papiya Hill above Brodilovo village, 370 m, July 2008.

\section{Eochorica balcanica (Rebel, 1919)}

According to Kozнаnтснікоv (1956) the forewing length (fringe included) in males varies from 9 to 10 but our measurements showed that it is $7.5-10 \mathrm{~mm}(\mathrm{n}=100)$. Forewing ground color varies from light to dark brown with yellow-whitish spots variable in size. Hindwing colour varies from light to dark brown. Females are wingless. This species occurs in warm and dry areas and flies in late July, August and September. At Demir Kapija it is syntopic with the recently described Eochorica vardarica Sobczyk, 2013. E. vardarica appears in the second half of October and the beginning of November, has a smaller forewing length of 7.2-8 mm, smaller length of antennae and has not such a contrasting wing pattern as E. balcanica (Sовсzук, 2013). Wing size should not be used as a sole character to distinguish these two species because they can slightly overlap. Other characters for secure determination are the shape of forewing scales and male and female genitalia (Soвczyк, 2013). According to SAuter \& HätTenschwiler (1996) E. balcanica is distributed in Albania, Bulgaria, FYR of Macedonia, Greece, Romania and Yugoslavia. In former Yugoslavia countries it is only reported from FYR of Macedonia (e.g. Rebel in Prinz, 1919; Thurner, 1941; Daniel, 1964). Rakosy et al. (2003) consider the reporting of E. balcanica in Romania unreliable and we follow their opinion. Its presence in Albania is questioned by WeIDLICH (2013). Out of the Balkan Peninsula it has been found in Turkey (DE FreinA, 1994). Rebel (1916) reported a very large and yellowish specimen of Penestoglossa dardoinella, collected in 1911 by Tschorbadjiev near Slivno [Sliven Town] in Bulgaria as a representative of the Tineidae family. Rebel stated his opinion that this might be variability in P. dardoinella or might represent a new undescribed species. This report in fact concerns E. balcanica. 
E. balcanica has not been known in Serbia before, thus it is a new genus and a new species for the country. We were not surprised to find this and other species with Mediterranean distribution in southern Serbia because the influence of Mediterranean climate coming through the Vardar and Pčinja river valleys is evident. Here we give two new localities for FYR of Macedonia and several new and confirmed localities for Bulgaria and Greece. The distribution gap between FYR of Macedonia, Bulgaria with Greek Eastern Macedonia and Thrace and Attica is now filled. Our knowledge on habitats confirms that $E$. balcanica is a xerothermic species. The great majority of the habitats are open with sparse vegetation, scattered bushes and trees and bare ground and rocks; the main threat to its existence could be the possibility that the habitats will become overgrown.

The following literature was used to compile a map (Fig. 1): BESHKov \& GoAter, 2000; BeshKov \& Langourov, 2004; BeshKov \& Langourov, 2011; BeshKov \& Nowacki, 1998; Daniel, 1964; Drenowsky, 1921; Drenowski, 1931; Kasy, 1956; Levy, 1968; Rebel in Rebel, 1915; Rebel, 1916; Rebel In Prinz, 1919; Rebel, 1940; RetZlaff, 1973; SobCZYK, 2013; ThurNer, 1936; Thurner, 1940; Weidlich, 1989; Weidlich, 2013; Witt, 1985; Zlatkov, 2007. DRENOWSKY (1921) was the first to report this species from area of Ohrid and Resen (as Resna) town and Mt Galičica, with just an elevation of $500 \mathrm{~m}$ [sic!] and no precise locality. The lowest elevation in that area is in Ohrid town, but at $700 \mathrm{~m}$. This elevation could be a printer's error. Later, DRENOWSKI (1930) mentioned E. balcanica in south-western Macedonia without a precise locality, which is probably a citation from his paper from 1921.

\section{Serbia}

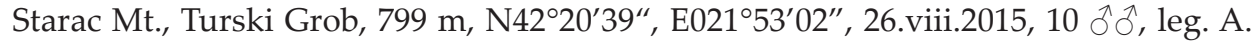
Nahirnić \& S. Beshkov, lamps and light traps

Preševo town municipality, 2 km W from Trnava village, 696 m, N42 $16^{\prime} 33^{\prime \prime}$, E02136' $57^{\prime \prime}$, 27.viii.2015, 35 ठठ, leg. A. Nahirnić \& S. Beshkov, serpentine steppes in forest belt of Quercus pubescens Wild. and Q. petraea (Matt.) Liebl. and thickets as result of degradation of this forest, lamps and light traps (Figs 4, 5)

\section{Macedonia}

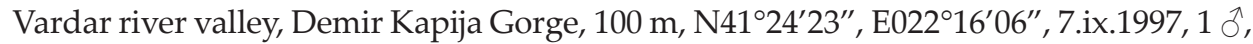
river valley with Platanus orientalis in limestone gorge, leg. S. Beshkov \& V. Gashtarov, lamp and light trap

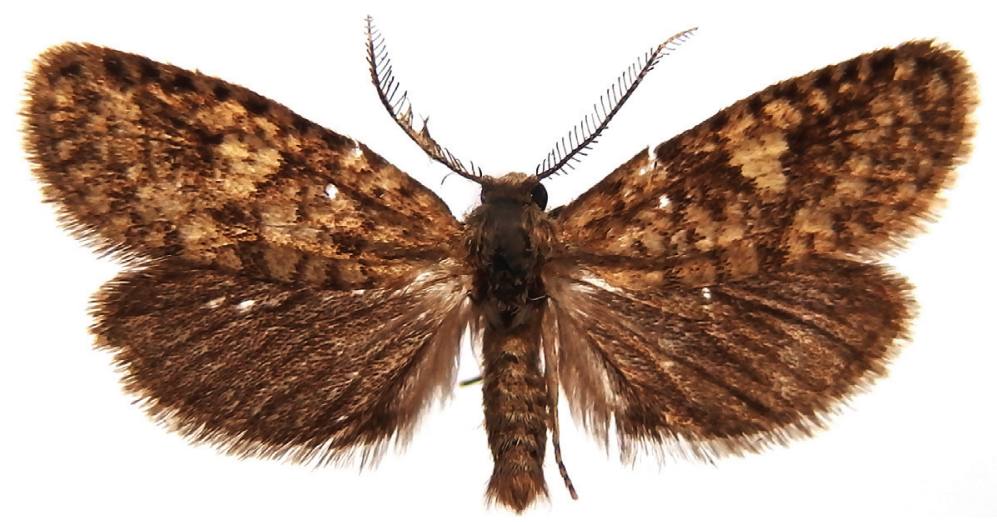

Fig. 4. Male of Eochorica balcanica (Rebel, 1919) from Preševo town municipality, $2 \mathrm{~km} \mathrm{~W}$ from Trnava village, $696 \mathrm{~m}$. 


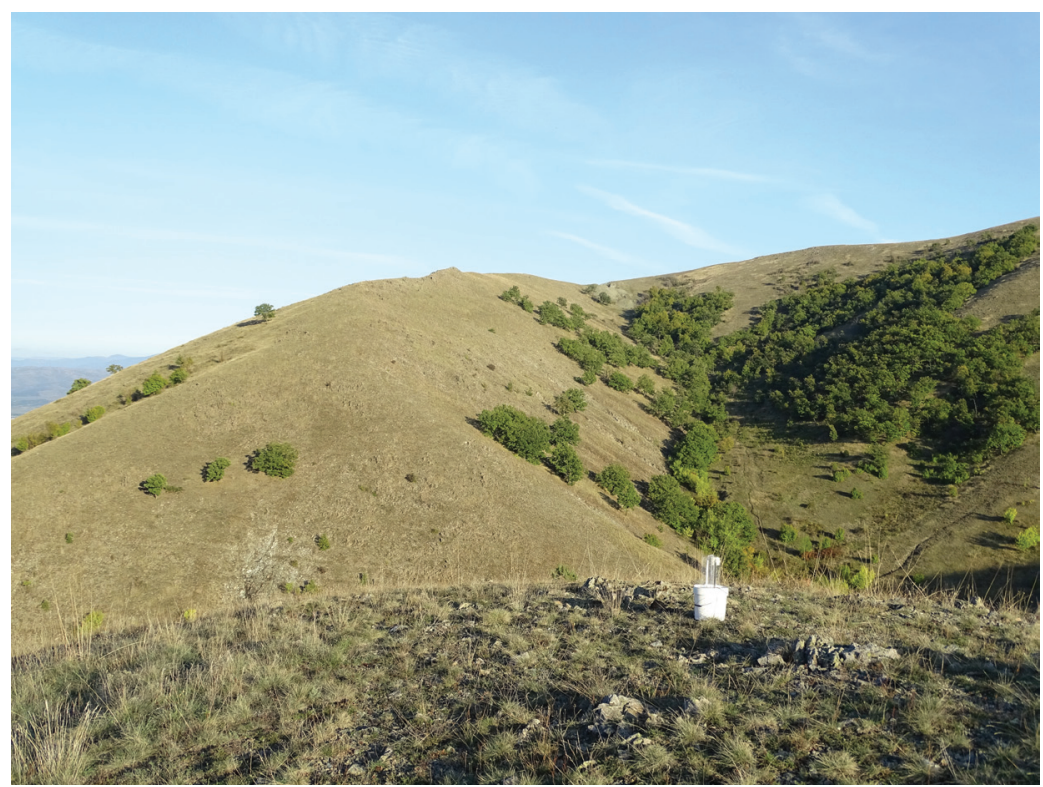

Fig. 5. Habitat of Eochorica balcanica (Rebel, 1919) at Preševo town municipality, $2 \mathrm{~km} \mathrm{~W}$ from Trnava village, 696 m, September 2015.

Babuna Mts, Prilep district, near Pletvar Pass, above Trojanci village, $740 \mathrm{~m}, \mathrm{~N} 41^{\circ} 23^{\prime} 07^{\prime \prime}$,

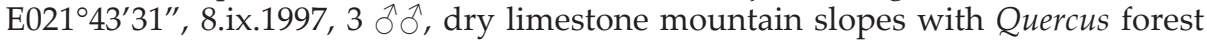
around, leg. S. Beshkov \& V. Gashtarov, lamp and light trap

\section{Bulgaria}

Kyustendil municipality, [Zemen Gorge] Skakavica, 1.ix.1980, 3 ふふふૈ, leg. J. Ganev (ZSM) Zemen Gorge, Skakavitza Railway station, 568 m, N42²4'54”, E02241'25”, 19.viii.1993, $1 \hat{\jmath}$, leg. V. Gashtarov, river valley in warm limestone area, lamp

Kresna Gorge, 23.viii.1980, 3 ふðð, leg. J. Ganev (ZSM)

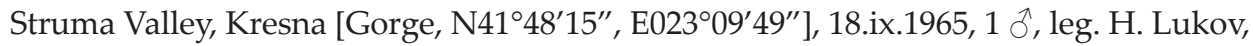
(IBER-BAS)

Pirin Mts - Kresna Gorge, Vlahi village, 556 m, N4144'27”, E02313'46", 28.viii.2009, 2

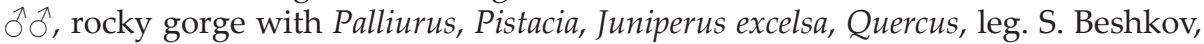
light traps and lamps.

Pirin Mts - Kresna Gorge, between Kresna town and Vlahi village, 482 m, N41 $44^{\prime} 21^{\prime \prime}$, E02312'18", 12.ix.2009, 1 § , rocky gorge with Palliurus, Pistacia, Juniperus excelsa, Quercus, leg. S. Beshkov, light trap.

Ograzden Mt., below Churicheni village, 670 m, N41²7'41”, E02308'30”, 05.ix.1999, 1 on, leg. S. Beshkov \& D. Vassilev, lamps

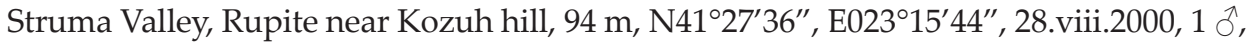
04.ix.1999, 1 ô, ruderal area below slopes with bushes, leg. S. Beshkov, lamps.

S Pirin Mts - Alibotush Mt, between Nova Lovcha and Paril village, Gradishteto, $756 \mathrm{~m}$,

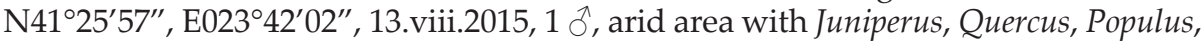
leg. B. Zlatkov, lamps and light traps 
Pazardzhik Region, Bessaparski Vazvisheniya Hills, Garkov Dol near Byaga village, 316 m, N42 03'60", E024²1'09”', 18.ix.2015, 1 ð’, meadow, leg. D. Kaynarov, light trap

Eastern Rhodopes, Kroumovgrad district, Ada Tepe, below Svezhest Chalet, 315 m,

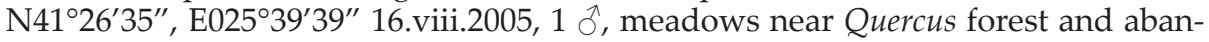
doned gardens, leg. S. Beshkov, $160 \mathrm{~W}$ MVL and $18 \mathrm{~W}$ black tube + light trap

Eastern Rhodopes, Ivaylovgrad district, „Meandrite na Byala Reka”, above Zhultichalskoto Dere Valley near Meden Buk village, 170 m, N4122'51", E02601'24" 15.ix.2006, $1 \hat{\jmath}$, dry area with Cystus in Quercus forest, leg. S. Beshkov \& B. Zlatkov, 160W MVL and $15 \mathrm{~W}+9 \mathrm{~W}$ black tubes and ultraactinidic light trap

Eastern Rhodopes Mts, Ivaylovgrad district, Byala Reka, Zhultichalskoto Dere near Meden Buk, $111 \mathrm{~m}, \mathrm{~N} 41^{\circ} 22^{\prime} 48^{\prime \prime}$, E02601'39", 8.ix.2014, 1 ô, Quercus, Tamarix, Alnus, leg. S. Beshkov \& S. Abadjiev, lamps and light traps.

Eastern Rhodopes, Ivaylovgrad district, Likana (Kodzhakaya) between Odrintzi and Belopolyane villages, $228 \mathrm{~m}, \mathrm{~N} 41^{\circ} 26^{\prime} 59^{\prime \prime}$, E0260'28', 16.viii.2014, 1 ○े, Phyllirea, Juniperus, Acer monspessulanum, Quercus, meadow, leg. S. Beshkov \& S. Abadjiev, lamps and light traps.

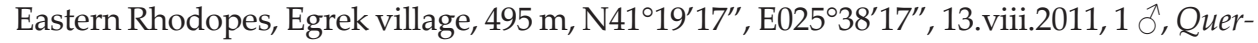
cus and Carpinus forest and open limestone stony meadows with Juniperus, leg. S. Beshkov, lamps and light traps.

\section{Greece}

Seres district, Menikio (Zmiinitza) Mts, above Timios Prodromos (Sveti Ivan) monastery near the abandoned village Lakosh, $442 \mathrm{~m}, \mathrm{N4} 1^{\circ} 09^{\prime} 15^{\prime \prime}$, E02332'46”, 19.ix.2000, 1 \% , dry stony mountain slopes with Mediterranean vegetation including Q. coccifera shrubs, leg. S. Beshkov, B. Petrov \& P. Stoev, lamp.

Drama, between Drama and Kato Nevrokopi, 391 m,N41 ${ }^{\circ} 13^{\prime} 21^{\prime \prime}$, E02358'16"', 6.ix.2013, $11 \hat{\jmath} \hat{\jmath}, Q$. coccifera shrublands on marble, leg. S. Beshkov, lamps powered by generator and light traps.

Halkidiki region, Katsika Mt., near Petralona cave, 365 m, N40²2'33", E02310'09”, 17.ix.2000, 1 § , Q. coccifera shrubs in a limestone area, leg. S. Beshkov, B. Petrov \& P. Stoev, lamps.

Trikala, Kalabaka, between Megalon Meteoron Monastery and Vlachavi village, $580 \mathrm{~m}$, N39 43'26", E02138'49", 31.viii.2010, 2 đ', Quercus forest and meadows, leg. S. Beshkov, lamps, light traps

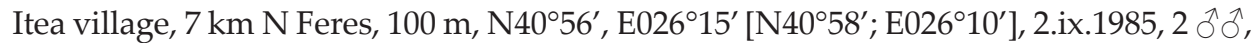
leg. H. Hacker, LF (MWM)

\section{ACKNOWLEDGEMENTS}

The first author is thankful to TLMF and MWM for funding her visit to these museums. We thank Viktor Gashtarov, Boyan Zlatkov and Dimitar Kaynarov for making their data available to us. Thomas Sobczyk and Michael Weidlich are thanked for information on species distribution. 


\section{REFERENCES}

Beshrov, S. \& Goater, B., 2000: Macrolepidoptera and Microlepidoptera (Alucitidae and Pyralidae) recorded in Bulgaria, 12-24 September 1995 (Lepidoptera). Historia naturalis bulgarica 12, 41-58.

Beshrov, S. \& Langourov, M., 2004: Butterflies and Moths (Insecta: Lepidoptera) of the Bulgarian part of Eastern Rhodopes. In: Beron P., Popov A. (eds), Biodiversity of Bulgaria. 2. Biodiversity of Eastern Rhodopes (Bulgaria and Greece). Pensoft \& National Museum of Natural History, Sofia. p. 525-676.

Beshrov, S. \& Langourov, M., 2011: Nocturnal and Day-flying Moths (Macrolepidoptera, Excluding Hesperioidea \& Papilionoidea) of the Bulgarian part of Western Rhodopes. In: Beron P., Popov A. (eds), Biodiversity of Bulgaria. 4. Biodiversity of Western Rhodopes (Bulgaria and Greece) II. Pensoft \& National Museum of Natural History, Sofia. p. 299-484.

Beshкov, S. \& Nowacki, J., 1998: New records of Macrolepidoptera from Bulgaria. Rocznik Muzeum Górnośląskiego Przyroda 15, 45-51.

Chrétien, P., 1916: Contribution à la connaissance des Lépidoptères du Nord de l'Afrique. Notes biologiqueset critiques. Annales de la Société entomologique de France 85(3/4), 369-502.

Daniel, F., 1964: Die Lepidopterenfauna Jugoslawish Mazedoniens. II. Bombyces et Sphinges. Posebno izdanie. Museum Macedonicum Scientarum Naturalium Skopje 2, 1-75.

DE FreinA, J. J., 1994: 9. Beitrag zur systematischen Erfassung der Bombyces- und Sphinges-Fauna Kleinasiens. Weitere Kenntnisse über Artenspektrum, Systematik und Verbreitung von Cossidae, Psychidae, Cochlididae, Syntomidae, Saturniidae, Brahmaeidae, Drepanidae, Axiidae, Hepialidae, Dilobidae und Nolidae (Insecta, Lepidoptera). Atalanta 25(1/2), 317-349.

Drenowsky, A. K., 1921: Zur Lepidopterenfauna Mazedoniens. Zeitschrift für Wissenschaftliche Insektenbiologie 16(9/10), 164-166.

Drenowski, A. K., 1930: Beitrag zur Lepidopterenfauna S. W. Mazedoniens. Journal of the Bulgarian Academy of Sciences 45(22), 129-177. (in Bulgarian, German summary)

DrenowsKI, A. K., 1931: Zweiter Verzeichnis der auf dem Alibotuschgebirge gesammelten Lepidopteren (In bulgar. N.O. Mazedonien). Mitteilungen der Bulgarischen Entomologischen Gesellschaft in Sofia VI, 49-67. (in Bulgarian, German summary)

Galvagni, E., 1909: Die Zoologische Reise des Naturwissenschaftlichen Vereines nach Dalmatien im April 1906. B. Spezieller Teil. Bearbeitung des gesammelten Materials. 13. Lepidoptera (Beiträge zur Kenntnis der Lepidopterenfauna der adriatischen Inseln) Mitteilungen des Naturwissenschaftlichen Vereins an der Universität Wien N. F. VII, 154-173, 177-244, 245-254.

KAsY, F., 1956: Ergebnisse einer lepidopterologischen Sammel- und Studienreise nach Ochrid in Westmazedonien im Sommer 1955. Entomologisches Nachrichtenblatt (N. F.) 3 (7), 3-6.

Kozhantchikov, I. V., 1956: Fauna der UdSSR, Psychidae. Academy of Science USSR. Moscow, Leningrad: p 517 pp. [in Russian]

LEVY, J., 1968: Zur Schmetterlingsfauna der bulgarischen Schwarzmeerküste. Entomologische Nachrichten Dresden 12(10), 105-114.

Rakosy, L., Goya, M. \& Kovacs, Z., 2003: Verzeichnis der Schmetterlinge Rumäniens. Societatea Lepidopterologică Romană. Cluj-Napoca: 447 pp.

Rebel, H., 1891: Beitrag zur Lepidopterenfauna Dalmatiens. Verhandlungen zologisch-botanischen Gesellschaft in Wien 41, 610-639.

Rebel., H. in Rebel H., 1915: Bericht der Sektion für Lepidopterologie. Versammlung am 4. Dezember 1914. Verhandlungen der zoologisch-botanischen Gesellschaft Wien 65, (50)-(59).

Rebel, H., 1916: Beitrag zur Lepidopterenfauna Bulgariens. Verhandlungen der Zoologisch-Botanischen Gesellschaft in Wien 66, (36)-(46).

Rebel, H. in Prinz, J., 1919: Bericht der Sektion für Lepidopterologie. Versammlung am 7. März 1919. Beitrag zur Kenntnis paläarktischer Mikrolepidopteren. Verhandlungen der zoologisch-botanischen Gesellschaft Wien 69, (126)-(135).

Rebel, H., 1940: Zur Kenntnis einiger Subfamilien der Psychiden. Zeitschrift des Wiener EntomologenVereines 25(3), 59-65, (4), 73-76.

Retzlaff, H., 1973: Ein Beitrag zur Psychiden-Fauna Jugoslavisch-Mazedoniens (Lep.). EntomologischeZeitschrift 83, 7, 77-80.

Sauter, W. \& Hättenschwiler, P., 1996: Psychidae. In: Karsholt O. \& Razowski, J. (eds.): The Lepidoptera of Europe. A Distributional Checklist. Psychidae. Apollo Books, Stenstrup, pp.: 39-46.

Sовсzүк, T., 2011: Psychidae (Lepidoptera). In: Nuss, M. (ed.), World Catalogue of Insects 10. Apollo Books, Stenstrup: 467 pp. 
Soвсzук, T., 2013: Eochorica vardarica und Penestoglossa sutteri - zwei neue Arten der Typhoniinae aus Südeuropa (Lepidoptera: Psychidae). EntomologischeZeitschrift 123(1), 19-24.

Sовсzүк, T., Bläsıus, R. \& Nuss, M., 2016: Revision der nordafrikanischen Arten der Gattungen Penestoglossa Rogenhofer, 1875, Dissoctenioides Rebel, 1935 und Pseudofumea Rebel, 1935 (Lepidoptera, Psychidae). Entomofauna 37(41), 629-684.

Thurner, J., 1936: Einige bemerkenswerte Lepidopterenfunde aus Mazedonien. Zeitschrift des Österreichischen Entomologen Vereines 21, 6-7, 13-15.

Thurner, J., 1941: Die Schmetterlinge der Ochrid Gegend in Macedonien II Teil Microlepidoptera. Mitteilungen aus den Königlichennaturwissenschaftlichen Instituten in Sofia 14, 9-35.

Weidlich, M., 1989: Abriß der Psychidenfauna Bulgarisch-Mazedoniens mit der Erstbeschreibung des Weibchens und Sackes von Reisseronia nigrociliella (Rebel, 1934) (Lepidoptera, Psychidae). Nachrichtenblatt der Bayerischen Entomologen 38(1), 1-12.

Weidlich, M., 2013: Zur Schmetterlingsfauna des Pangéo in Griechisch-Mazedonien mit Beschreibung von Dahlica pangeoensis nov. sp. und Bemerkungen zur Köcherfliegenfauna (Lepidoptera, Trichoptera). Linzer Biologische Beiträge 45(1), 945-969.

WiтT, T., 1985: Neue und bemerkenswerte Heterocerennachweise aus Griechenland (Lepidoptera, Arctiidae, Lymantriidae, Thyatiridae, Psychidae). Nachrichtenblatt der Bayerischen Entomologen 34(2), 47-49.

ZLATKov, B., 2007: Butterflies and moths (Lepidoptera: Macrolepidoptera) of Mesta Valley in SW Bulgaria. Historia naturalis bulgarica 18, 95-126.

\title{
SUMMARY
}

\section{New records of Penestoglossa dardoinella (Millière, 1863) and Eochorica balcanica (Rebel, 1919) (Lepidoptera: Psychidae) on the Balkan Peninsula}

\author{
A. Nahirnić \& S. Beshkov
}

The family Psychidae by domestic authors on the Balkan Peninsula was mostly mentioned occasionally and usually in faunistic publications which included several Lepidoptera families. Here we give a review of the distribution of two Psychidae in the Balkan Peninsula Penestoglossa dardoinella (Millière, 1863) and Eochorica balcanica (Rebel, 1919). Our paper contains results of lepidopterological field surveys on the Balkan Peninsula by several collectors carried out in the last 25 years. We also included some additional unpublished data from museum collections.

New records of $P$. dardoinella are given for Bulgaria and Greece and one confirmed record for Croatia. Mt Strandza represents the easternmost point of the range of this species in Europe. It is a new genus and species for Bulgaria.

New and confirmed records of Eochorica balcanica (Rebel, 1919) are provided for Bulgaria, FYR Macedonia and Greece. E. balcanica has also been collected in southern Serbia, which makes it a new genus and a new species for the Serbian fauna. The distribution gap between FYR Macedonia, Bulgaria with Greek Eastern Macedonia and Thrace and Attica is now filled.

Not only light trapping but also collection of cases together with rearing would increase the number of records of both species. 